\title{
ROMANTYZM JENAJSKI, CYPRIAN NORWID, WALTER BENJAMIN I FRIEDRICH CREUZER: SYMBOL I ALEGORIA
}

Słowa kluczowe: miasto, ruiny, symbol, alegoria, romantyzm

Keywords: town, ruins, symbol, allegory, romanticism

1.

Pod względem wykorzystywania symbolicznego potencjału świata zjawiskowego Norwid, poeta i „sztukmistrz”, okazuje się krytykiem (a w tym sensie także kontynuatorem) nurtu romantyzmu, który niewiele ma wspólnego z twórczą praktyką większości polskich romantyków (skupiali się oni - zwłaszcza po powstaniu listopadowym - na etycznych i historiozoficznych konsekwencjach rozbiorów i nieudanych prób odzyskiwania niepodległości). Nie oznacza to, że Mickiewicz, Słowacki i Krasiński, a także romantyczni filozofowie, jak Cieszkowski i Trentowski, nie poświęcili uwagi epistemologicznym uwarunkowaniom romantycznego podmiotu (takim jak refleksyjność, ironia romantyczna, relacja między idea a ideałem, transcendentalność itd.), ale ich znaczenie było jednak podporządkowane specyficznej, „narodowej” interpretacji „historii świętej”. Norwid był pod tym względem wyjątkiem, chociaż nie nawiązał bezpośrednio do spekulacji wczesnych romantyków niemieckich, którzy - jak np. Friedrich Schlegel w słynnych Athenäums-fragmente - interpretowali rolę poezji w kontekście pojęć i terminów zaczerpniętych z idealistycznej filozofii „transcendentalnej” (por. Schleglowski temin „Transzendentalpoesie” - z drugiej strony to również „poezja” miała zmodyfikować „filozofię”, ponieważ ta ostatnia nie mogła o własnych siłach osiagnacć i wypowiedzieć „Absolutu”). Podstawą tego wszechpoetyckiego światopoglądu okazuje się relacja między symbolem i alegorią, ponieważ nie ma aspektu rzeczywistości, którego - zdaniem wczesnych romantyków niemieckich - nie można by ująć w tych figurach ${ }^{1}$. Symbol (a także alegoria

${ }^{1} \mathrm{~W}$ spekulacjach poetologicznych Novalisa i Friedricha Schlegla różnica między symbolem a alegorią pozostaje płynna. Dopiero Friedrich Creuzer, nawiązując do Goethego, wyszczególnił te 
w tej mierze, w jakiej u romantyków jej pole znaczeniowe zbiega się z symbo$\mathrm{lem}^{2}$ ) nie jest przy tym bytem zewnętrznym wobec przedmiotów symbolizowanych. On sam i ze swej strony może być przez się symbolizowany. Można go bowiem również samego traktować jako symbol - staje się on wtedy przedmiotem czynności symbolizującej z perspektywy własnego desygnatu. Tę wysoce ambiwalentną cechę symbolu, decydującą o jego uniwersalności, omawia Novalis w jednym ze swoich słynnych fragmentów:

Jedes Symbol kann durch sein Symbolisiertes wieder symbolisiert werden - Gegensymbole. Es gibt auch Symbole der Symbole - Untersymbole.

Auf Verwechslung des Symbols mit dem Symbolisierten - auf ihre Identisierung - auf den Glauben an wahrhafte, vollständige Repräsentation, und Relation des Bildes und des Originals, der Erscheinung und der Substanz - auf der Folgerung von äußerlicher Ähnlichkeit - und durchgängige innre Übereinstimmung und Zusammenhang - kurz auf Verwechslungen von Subjekt und Objekt, beruht der Aberglaube und Irrtum aller Zeiten, und Völker und Individuen. [...] Symbolistik des menschlichen - der Tierwelt - der Planzenwelt - der Natur - der Mineralien - der Atmosphärilien - der Meteore - der Gestirne - der Empfindungen - Gedanken - der Seele - der Geschichte - der Mathematik. (Alles kann Symbol des andern sein - symbolische Funktion.).

Ciekawy jest tu przede wszystkim kontekst, w którym Novalis formułuje swą teorię powszechnej symboliczności bycia. Ulega zniesieniu nie tylko dualizm między podmiotem a przedmiotem, lecz również wszystkie inne opozycje logiczne porządkujące akty poznawcze okazują się fałszywe. Przyczyną tego „nieporozumienia” (Novalis używa tu nawet określenia „zabobon”) wydaje się postulat

kategorie. Właśnie w postaci nadanej im przez Creuzera, autora wielotomowego dzieła Symbolik und Mythologie der alten Völker, zostaną one podjęte i przeinterpretowane przez Waltera Benjamina w słynnej rozprawie o źródłach niemieckiej tragedii żałobnej (Ursprung des deutschen Trauerspiels).

${ }^{2}$ W Prelekcjach o literaturze pięknej $i$ sztuce August Wilhelm Schlegel wyjaśnia to szersze znaczenie pojęcia alegorii na przykładzie mitów Homera. Nie odrzuca przy tym kategorycznie ich alegoryczności, postuluje jedynie, byśmy nie traktowali alegorii jako „wyrozumowane i umyślnie wynalezione przyoblekanie pojęcia w obraz" [,die besonnene und absichtlich erfundne bildliche Einkleidung eines Begriffs”]. Uważa on jednak, że podstawą tych mitów jest raczej „fantazmat” (Phantasiebild), który jest bardziej źródłowy od pojęć oderwanych [A.W. Schlegel, Vorlesungen über die schöne Literatur und Kunst, vol. 1, 338-339].

${ }^{3}$ Novalis, Schriften (Berlin, 1983), vol. 3, 397. „Każdy symbol może być znów symbolizowany poprzez własne symbolizowane - chodzi o symbole przeciwstawne.

Istnieją także symbole symboli - pod-symbole. Błąd wszystkich czasów, ludów i jednostek, całość przesądu opiera się na pomyłce pojmowania, na zamianie symbolu i symbolizowanego, na ich utożsamianiu - na wierze w prawdziwą, pełną reprezentację oraz relacje obrazu $\mathrm{z}$ oryginałem, zjawiska i substancji - na wnioskowaniu o zewnętrznym podobieństwie - i poprzez wewnętrzny, przejściowy związek i zgodność - na myleniu podmiotu z obiektem. [...] Symbolika ludzkiego ciała - świata zwierząt - świata roślin - natury - minerałów - gazów atmosferycznych - meteorów - ciał niebieskich - odczuć - myśli - duszy - historii - matematyki. (Wszystko może być symbolem innego - funkcja symboliczna)”. Przekłady z języka niemieckiego - Alina Molisak, chyba że wskazano inaczej. 
całkowitej tożsamości między „obrazem” a jego „pierwowzorem” (chociaż ich status oczywiście się różni). Taka tożsamość byłaby jedynie tautologią, gdyby nie to, że stwierdza ją jakiś podmiot, który jednak w tym akcie stwierdzającym tożsamość w dziedzinie przedmiotowej ujawnia (implicite) swą własną nietożsamość z ,ja” poprzedzającym ów akt poznawczy. W romantycznej koncepcji refleksji ów moment nietożsamości „różnicuje” sam podmiot aktu poznawczego (chodzi tu o poznawanie w szerszym tego słowa znaczeniu: nie ogranicza się ono do aktów czysto intelektualnych, „pojęciowych”; jest np. również podstawą poezji). Ów moment różnicy staje się treścią kolejnego (z innej perspektywy „równoczesnego") aktu samopoznawczego. Tym samym okazuje się jednak, że „wewnętrzna zgodność symbolu z symbolizowanym” stwierdzona przez podmiot tylko pozornie wewnętrznie zgodny z sobą jest nieporozumieniem. Ową samoświadomość podmiotu, polegającą na stwierdzaniu swojej nietożsamości z sobą, można rozumieć tylko jako nieskończony szereg aktów autorefleksji. Są one warunkowane przez możliwość podważania tautologicznych aktów poznawczych, które ustalają w świecie zjawisk stałe relacje identyczności między przedmiotami na zasadzie istoty i pozoru, obrazu i oryginału etc. Idea absolutu ulega więc relatywizacji, albo - inaczej - relacyjność aktów podmiotowych staje się swoistym przeciw-absolutem.

Konsekwencją takiego stanu rzeczy jest możliwość odwracania relacji między treściami składającymi się na czysto „logiczne” operacje. Treści te (a także łączące je relacje logiczne) wchodzą bowiem jako elementy żywej refleksji w coraz to nowe konteksty poznawcze. Wydaje się przy tym, iż również prze(d)sąd, że to, co fizyczne, „materialne”, jest bardziej „prawdziwe” (bo „bezpośrednio” dane zmysłom) niż to, co duchowe, metafizyczne (nie należy mylić tej opozycji z różnicą między „ciałem” a „duszą”), traci swą rację istnienia. Obydwie te perspektywy epistemologiczne łączy bowiem to, że przejawiają się jako treść podmiotowych aktów poznawczych (istotnym składnikiem tych aktów jest również świadomość podmiotu poznającego samego siebie). Są zatem już zapośredniczone (vermittelte) i mogą stawać się treścią nowych zapośredniczeń. Proces romantycznej refleksji jest tyleż nieskończony co wielokierunkowy.

Następstwa tej teorii są dalekosiężne. Spróbujmy w związku z tym dokładniej przeanalizować przytoczony wyżej fragment Novalisa. Pisząc o „ubiorze jako symbolu” [Über den Anzug - als Symbol], Novalis doszedł do wniosku, że „ubiór jest symbolem ducha czasów" ". Czy można odwrócić to twierdzenie? Oczywiście nie w sposób mechaniczny („duch czasów jest symbolem ubioru”). Jak się wydaje, relacja między materialnością bytu (ubiór nie jest przecież tylko czymś „materialnym”, lecz służy przede wszystkim pewnemu celowi, może raczej różnym celom - „praktycznym” i „estetetycznym”) a „pojęciową” sferą historiozofii

\footnotetext{
${ }^{4}$ Ibidem, 397.
} 
daje się ustalić pośrednio, poprzez człowieka, który łączy świat fizykalny z dziedziną kategorii intelektualnych i duchowych, takich jak przyczynowość, celowość, a także harmonia. „Ubiór” jako treść aktów intelektualnych (inaczej: jako produkt czynnej podmiotowości) jest samozapośredniczeniem się człowieka, którą to można następująco zmodyfikować: „podmiotowość zapośrednicza się poprzez człowieka ujmującego pewne konkretne treści”. Relacja między tymi treściami nie jest stała, lecz kształtuje się poprzez żywy proces refleksji poetyckiej. W tej „symbolistyce ciała” wyszczególnia się również treść pojęcia „,człowieka". Wybierając konwencję ubioru, młodzieniec kieruje się innymi kryteriami (np. „lekkość” i „urozmaicenie”) niż dojrzały mężczyzna („skuteczność”) lub starzec (,wygoda”):

[...] Leichtigkeit und Mannigfaltigkeit und Geschicklichkeit statt der Bequemlichkeit - [ist der Charakter] der Jünglingskleidung, Zweckmäßigkeit der Charakter der männlichen Kleidung - Bequemlichkeit, Einfachheit und Dunkelheit der des Greises ${ }^{5}$.

Wobec tych aktów samookreślenia się (przez samoograniczenie) znaczenie pojęcia „człowiek” (jest ono logicznie nadrzędne wobec „młodzieńca”, „dojrzałego mężczyzny” i „starca”) ulega zachwianiu (relatywizacji). Z innej perspektywy można jednak za Novalisem powiedzieć, że „każde pojęcie jest jaźnią”6. Przez tę identyfikację człowiek jako istota ujmująca świat i samą siebie za pomocą pojęć otwiera się na nieskończoność. Samoograniczające się w pojęciu ,ja” uświadamia sobie w ten sposób bezgraniczność własnych horyzontów:

Je größer und höher das Ganze, desto merkwürdiger das Einzelne. Die Beschränkungsfähigkeit wächst mit der Schrankenlosigkeit ${ }^{7}$.

Właśnie tak wyglądają epistemologiczne uwarunkowania Schleglowskiej „idei”. Jest ona - w odróżnieniu od „pojęcia” - czynnikiem dynamicznym:

Eine Idee ist ein bis zur Ironie vollendeter Begriff, eine absolute Synthesis absoluter Antithesen, der stete sich selbst erzeugende Wechsel zwei streitender Gedanken ${ }^{8}$.

Człowiek jest organem podmiotowości par excellence wydobywającym symboliczność (często zapomnianą) wszystkich aspektów bycia. „Realny świat”

${ }^{5}$ Ibidem, 482-483. „Łatwość i różnorodność oraz zgrabność zamiast wygody - [to charakter] odzieży młodzieżowej, stosowność to charakter męskiej odzieży - wygoda, prostota i ciemne barwy - cechują ubiór starego człowieka".

${ }^{6}$ Ibidem, 485.

${ }^{7}$ Ibidem. „Im większa i wyższa całość tym bardziej interesujące to, co pojedyncze. Zdolność do ograniczenia rośnie wraz z nieograniczonością".

${ }^{8}$ Friedrich Schlegel, Kritische und theoretische Schriften (Stuttgart, 2002), 92. „Idea jest pojęciem aż do ironii doskonałym, absolutną syntezą absolutnych antytez, stale wytwarzającym się, generującym przeciwieństwa". 
okazuje się „pozorem” (por. Novalisa: „Der Realität ist der Schein”), tyle że dzięki tej negacji odzyskuje swoją prawdziwą wartość jako treść aktów podmiotowych, w których człowiek poprzez samoograniczenie się uobecnia nieskończoność bycia. Również sfera „realności” uzyskuje przez to status (nie rozpoznanego wprawdzie) symbolu (może tak właśnie trzeba rozumieć zagadkową formułę „przeciw-symbolu” we fragmencie Novalisa). Zadanie poety polega na aktualizowaniu owej potencjalnej symboliczności treści „realnych”. Pod tym względem romantyczne spekulacje epistemologiczne nie straciły nic ze swego znaczenia w drugiej połowie XIX wieku, kiedy akty poznawcze konstytuujące „realny świat” zawęziły swój zakres do faktów ustalanych przez tzw. nauki pozytywne. Spadkobiercy światopoglądu romantycznego (przewrotnym ich przedstawicielem był Cyprian Norwid) traktowali te fakty jako jeszcze jedną „partykularną” treść idei „zwalczających siebie myśli” według Fryderyka Schlegla. Wydobywali potencjalne znaczenia symboliczne tych faktów, zaprzeczając fałszywemu, czysto negatywnemu („,dwie absolutne antytezy”), „nierefleksyjnemu” absolutowi „ścisłej-wiedzy ogólników" , ocalając w ten sposób ideę nieskończoności.

W przypadku Norwida owa nieskończoność ma zawsze charakter sakralny w sensie chrześcijańskiej historii świętej, jak np. w następującym fragmencie z poematu Assunta:

\footnotetext{
„Człowieka stworzył 'tańcuch' przyrodzenia -

Mówił mi mąż ów - kość jest minerałem,

Dośrodkującym wilgoć w swoje rdzenia,

Zaś równowaga onych zwie się ciałem.

Płynów tam więcej niżeli krzemienia,

Skąd trupów lekkość (dodał to z zapałem)

Mierzy się według stopni osuszenia,

Tak że wielbłąda szkielet gdy skwar spali,

Wiatr nim porusza, jakby chciał biec daléj...”

„Dalej! - odrzekłem - za grób!” - i dodałem:

„Niepróżno łańcuch stworzenia (jak wyżéj

Rzekło się) nie jest stworzeń ideałem!...”10.
}

W świetle fizykalnych procesów powodujących rozkład ciała i „osuszenie” kościotrupa (nadające mu „lekkość”) fakt, że niczym jakaś żywa istota porusza się on o własnych siłach (jakby stanowił autonomiczny ośrodek bycia), jest tylko podsuniętym przez zmysły złudzeniem. Norwid zaś przenosi ten obraz (demaskując pozorną jednoznaczność i samowystarczalność ujmowanych przez zmysły bytów) na inny poziom, interpretując go jako symbol zaświatowej tęsknoty człowieka.

\footnotetext{
${ }^{9}$ Cyprian Kamil Norwid, Pisma wszystkie, vol. 3, ed. Juliusz Wiktor Gomulicki (Warszawa: PIW, 1971), 270. Dalej to wydanie oznaczam PW.

${ }^{10}$ Ibidem.
} 
Ten pozorny ruch (,jakby chciał biec daléj...”) staje się przy tym dowodem, że człowiek na różne sposoby ujmuje transcendencję. „Abstrakcyjne” pojęcia mu nie wystarczają. Kontekstualizuje je więc poprzez wydobycie nowych - symbolicznych - znaczeń z otaczającej go rzeczywistości - zmysłowej i duchowej (określenie „za grób!” odświeża bardziej utartą formułę „za-świat”, łącząc wcześniejszą konkretyzację idei nieskończoności, która straciła swą naoczność, bezpośrednio ze zmartwychwstaniem ${ }^{11}$ ).

Romantyczna relatywizacja ,ja” (jej korelat stanowi absolutyzacja podmiotowości - przekracza ona bowiem - w paradoksalny sposób - poziom indywiduacji) nie daje się jednak łatwo pogodzić ze światopoglądem chrześcijańskim (choć np. Friedrich Schlegel i Joseph Görres nawrócili się na katolicyzm). Z punktu widzenia dogmatów chrześcijańskich romantyczna transcendencja nie idzie bowiem w parze z sacrum. Dla romantyka „każde pojęcie jest jaźnią”, staje się specyficznym ośrodkiem, otwierającym perspektywę na nieskończoną rzeczywistość. Ale istotny dla chrześcijaństwa akt wcielenia słowa-logosu pozwalający ustalić relację z historyczną chwilą narodzin, zgonu i zmartwychwstania Chrystusa, traci w światopoglądzie wczesnego romantyzmu niemieckiego swój uprzywilejowany status. Po pierwsze dlatego, że opozycja między ciałem a duchem staje się treścią procesu refleksji zmierzającej do zniesienia wszelkich różnic ,istotowych”, podczas gdy w chrześcijaństwie Chrystus jako pośrednik uobecnia i wciela niemożliwość pogodzenia tych przeciwieństw (w historycznie niepowtarzalnym momencie Jego narodzin zostały one jednak pogodzone - choć nie zniesione). Po drugie ponieważ romantyczna koncepcja refleksji podważa unikatowy charakter chrześcijańskiej historii świętej. Na etapie Athenäumsfragmente Friedrich Schlegel odrzucał ideę jednego tylko pośrednika. Byłoby to sprzeczne z nieskończonością podmiotowej refleksji stanowiącej podstawę wolności jako zasady bycia. Podobnie jak wszystko dla podmiotu może być symbolem (włącznie z samymi symbolami), „doskonały chrześcijanin” (nazwiskiem jego okazuje się niespodziewanie filozof Spinoza) odnajduje więc wszędzie pośredników:

Es ist sehr einseitig und anmaßend, daß es gerade nur Einen Mittler geben soll. Für den volkommenen Christen, dem sich in dieser Rücksicht der einzige Spinosa am meisten nähern dürfte, müßte wohl alles Mittler sein ${ }^{12}$.

${ }^{11}$ Jest to podstawowy motyw w poezji Norwida. Ów jakościowy „skok” kontekstualizuje się poprzez coraz nowe konfiguracje wzajemnie modyfikujących się obrazów i pojęć, jak np. w Pieśni IV Assunty: „Świat tak się mały stał nam - że pod stopy / Czuliśmy obrót głowy - - - / - trzeba było / Nowy wynaleźć, przeszedtszy okopy / Rzeczywistości, z weselem i siłą” (ibidem, 290-291).

${ }^{12}$ Friedrich Schlegel, op. cit., 104. „To bardzo tendencyjne i narzucające się, że powinien istnieć tylko jeden pośrednik. Dla doskonałych chrześcijan, ku którym w tym względzie najbardziej mógł się zbliżyć jedynie Spinoza, wszystko musiałoby być pośrednikiem”. 
Akceptując tezę o powszechności pośredników, zakładamy, że jakiś jednostkowy podmiot zakończył już proces samopośredniczenia się poprzez nieskończony szereg aktów refleksyjnych (są one „modyfikacjami” jedynego bycia), a różnica między immanencją a transcendencją uległaby zniesieniu ${ }^{13}$. Warunkiem tej indywidualnej świadomości powszechnego pośredniczenia jest przekonanie, że wszystkie akty zapośredniczające są potencjalnie aktami samopośredniczenia. Symboliczność bytów składających się na wszechświat straciłaby wtedy swą podstawę (por. Novalisa: „Am Ende weiß der Denker aus jedem alles zu machen”"14). Refleksja jako (być może nieskończony) szereg aktów ujmowania świata przez samoograniczający i samozapośredniczający się podmiot polega bowiem na tym, że jakieś partykularne „ja” porządkuje rzeczywistość tak, że jawi się ona jako fragment wskazujący na scalającą (i $-\mathrm{z}$ chrześcijańskiego punktu widzenia - ocalającą) ją całość. Jedynie w takich warunkach - mówiąc po Norwidowsku: biorąc pod uwagę nierozwiązywalne napięcie między „brakiem” a pełnią - treść jego refleksji staje się symbolem. Koncepcja powszechności pośredników likwiduje jednak to napięcie, które wiąże się ściśle z obrzędową sferą sacrum ${ }^{15}$. Poznawanie sakralnej istoty bycia stawałoby się wówczas możliwe bez obrzędów (rytuałów), które zawsze inscenizują jakiś pierwowzór. Innymi słowy: jeśli podmiot chce

${ }^{13}$ Wydaje się jednak, że w tym swoistym absolucie nie znika wszelka różnica. W „poezji transcendentalnej” absolutna różnica między „realnym” a „idealnym” przeobraziła się w absolutną tożsamość (dokonał tego gatunek „idylli”), tyle że istotnym czynnikiem tej absolutnej tożsamości jest refleksja krytyczna jako świadomość procesu rozwoju literackiego.

${ }^{14}$ Novalis, op. cit., 485.

${ }^{15}$ Podobną, w istocie „mesjańską” (wprawdzie w kontekście „mistyki żydowskiej”) intuicję sformułował Walter Benjamin w swoich tezach „O pojęciu historii” (Über den Begriff der Geschichte), tyle że u niego połączenie idei zbawiciela z perspektywa „transcendentalną” ulega uhistorycznieniu. Z punktu widzenia dziejów żadna chwila nie zostaje stracona, choć dopiero „zbawionej ludzkości” przypadnie „cała jej przeszłość”: „Das will sagen: erst der erlösten Menschheit ist ihre Vergangenheit in jedem ihrer Momente zitierbar geworden”. Walter Benjamin, Gesammelte Schriften, ed. Rolf Tiedemann, Hermann Schweppenhäuser (Frankfurt am Main, 1974), vol. I.2, 694 (dalej to wydanie oznaczam GS). Przejście na poziom zbawienia okazuje się tu jednak „skokiem” jakościowym (to coś więcej niż Heglowski „Umschlag”, bo nie wynika samorzutnie z procesu historycznego). Słabość filozofii transcendentalnej polega z takiej perspektywy na tym, że brakuje w niej koncepcji „skoku” (por. krytykę Hegla przez Kierkegaarda). Może właśnie dlatego Fr. Schlegel nie zadowalał się przejętą od Fichtego filozofią podmiotowości i (podobnie jak Schelling) stopniowo ewoluował w stronę światopoglądu religijnego. Właśnie tym etapem rozwojowym niemieckiej filozofii idealistycznej interesował się później (w Prelekcjach Paryskich) Adam Mickiewicz, a także Cieszkowski i Trentowski. Transcendentalny punkt wyjścia nigdy nie uległ u nich jednak całkowitemu zatarciu. Ogromne znaczenie myśli polskiej filozofii romantycznej dla Norwida nie ulega kwestii, a właśnie w taki sposób zapoznał się on (wprawdzie pośrednio) ze strukturami myślenia transcendentalnego. Cf. Jadwiga Puzynina, „ «Prawda» Norwida jako hieroglif”, in Hieroglifem zapisane. Cyprian Norwid, ed. Tomasz Korpysz et. al. (Warszawa: Wydział Polonistyki Uniwersytetu Warszawskiego, 2012), 90-91; autorka tego tekstu, przypominając kontekst „niemieckiego przełomu klasyczno-romantycznego”, uważa jednak, że Norwid zupełnie inaczej rozwijał „pojęcie całości”, przy czym opierał się przede wszystkim na tradycyjnych koncepcjach teologii katolickiej. 
rozpoznać symboliczność jakiejś sytuacji (lub przedmiotu) w stosunku do chrześcijańskiej odmiany transcendencji, powinien odnieść ją do historii świętej i do jej centralnej postaci, Chrystusa, który jako wcielone Słowo jest jedynym pośrednikiem między Bogiem (absolutną transcendencją) a sferą immanencji. Taki podmiot zapośrednicza zatem coś, co zostało już zapośredniczone przez samo bóstwo, które, udzielając się światu (stając się swoim własnym pośrednikiem), w pewnym sensie samo się ograniczyło. Pod tym względem istnieje wprawdzie pewne podobieństwo między romantycznym (w sensie „Schleglowskim”) podmiotem („Die Beschränkungsfähigkeit wächst mit der Schrankenlosigkeit” - więc też: jego wiedza rozszerza się w miarę, jak sam się ogranicza) a ideą pośrednika wyłaniającą się z chrześcijańskiej teologii spekulatywnej. Jednakże w światopoglądzie wczesnych romantyków nie udało się sformułować tej relacji w taki sposób, by drugą stroną owego podobieństwa była absolutna różnica, a tylko pod tym warunkiem idea pośrednika zachowuje swą autonomię ontologiczną i egzystencjalną.

2.

„Podmiotowy” i refleksyjny nurt romantyzmu analizowany w pierwszej części tego tekstu był bardzo ważny dla kształtujących się w XIX wieku poetyckich ujęć symbolu (oraz prób rozgraniczenia go z alegorią). Właśnie tą drogą wyobrażenia o symbolu trafiły do niemieckiego krytyka, eseisty i filozofa Waltera Benjamina. Autor rozprawy o Źródle dramatu żałobnego $w$ Niemczech ${ }^{16}$ próbował jednak udowodnić, że romantyczne rozważania o symbolu polegały na istotnym nieporozumieniu. Jego zdaniem romantycy (Benjamin myślał tu przede wszystkim o spekulacjach poetologicznych Friedricha Schlegela i Novalisa, którym poświęcił swój doktorat pt. Der Begriff der Kunstkritik in der deutschen Romantik) stosowali koncepcję symbolu zakorzenioną w teologii, by określić relację między „ideą” a jej realizacją w dziele sztuki. Zadanie tego „symbolu teologicznego” polegało jednak pierwotnie na tym, by ująć - albo przynajmniej unaocznić - niesymetryczną relację między bóstwem (sacrum) a sferą profanum. W romantycznej „teo-poetologii” opozycja ta uległa jednak przeobrażeniu. Idea reprezentuje bowiem sferę nieskończoności, podczas gdy dzieła stanowią pewnego rodzaju „wszystkość”. Będąc częścią, utwór pragnie być całością, i właśnie jako „intencja” ukierunkowana na transcendencję ustala rzeczywistą relację między „nieuwarunkowanym” a immanencją. Dzieło sztuki warunkuje zatem nieuwarunkowane, albo odwrotnie: absolut warunkuje się w utworze, tzn. ogranicza siebie jako formę) $)^{17}$.

${ }^{16}$ Polski przekład słynnej (ale niedoszłej) pracy habilitacyjnej Benjamina Ursprung des deutschen Trauerspiel (autor pisał ją w latach 1924-1925) ukazał się w roku 2013. Cf. Walter Benjamin, Źródto dramatu żałobnego w Niemczech, trans. Andrzej Kopacki, ed. Adam Lipszyc (Warszawa: Sic!, 2013).

${ }^{17}$ Walter Benjamin, Gesammelte Schriften, vol. I.1, 115. 
U innych twórców, kontynuujących tradycję Goetheańskiego „Urbild”, kategorią pośredniczącą między owym „prawzorcem” a konkretnym dziełem sztuki stawało się zaś piękno. Samo dzieło miało status „torsu”, odłamku. Może ono w stosunku do innych dzieł uzyskać rangę kanoniczną (tak stało się - zdaniem Goethego - w przypadku starożytnej sztuki greckiej), ale przepaść ontologiczna między konkretnymi utworami sztuki a sferą prawzorców pozostaje nie do pokonania. Różnica ze stanowiskiem głoszonym przez przedstawicieli Schleglowskiej odmiany romantyzmu rzuca się w oczy. Najjaśniej ujmuje tę różnicę sam Benjamin w aneksie do swojej rozprawy doktorskiej. Porównując koncepcję romantyczną z Goetheańską, zwraca uwagę, że u romantyków „dzieło sztuki nie może być torsem, musi być ruchomym, mijającym momentem w żywej formie transcendentalnej" ${ }^{18}$. Innymi słowy: dzieło sztuki nie istnieje poza procesem mediacji. Jest wynikiem aktu samoograniczenia się, poprzez który ujmuje siebie jako skończoną, „przypadkową” formę. Uwiecznia się natomiast (ten moment Benjamin podkreśla) jako przedmiot krytyki, czyli - jak teraz powiedzielibyśmy - jako możliwość coraz to nowych aktów rekonstektualizujących dzieło wobec nowych konfiguracji. Istotne wydaje się tu, że samograniczenie, skończoność stanowi warunek nieskończoności idei sztuki. Jej transcendencja ma więc zupełnie inny charakter niż transcendencja Goetheańskiego prawzorca („Urbild”), który „według swojej epistemologicznej determinacji” jest ideą „w sensie platońskim"19.

W obu tych odmianach konstruowania relacji między „ideą” (albo „ideałem) sztuki a jej realizacjami (po Norwidowsku: „przybliżeniami”) konkretne dzieła nabierają sensów symbolicznych. Symbol okazuje się uprzywilejowaną figurą romantyków, ponieważ paradoksalna ,jedność przedmiotu zmysłowego i nadzmysłowego", charakterystyczna dla „symbolu teologicznego”, łatwo może być sprowadzona (Benjamin do tego podchodzi bardziej stronniczo i pisze: „wypaczona”) do kategorii „pojęciowej”, tzn. „relacji między zjawiskiem a istotą”. Alegorię zaś zarówno Goethe, jak i romantycy wprawdzie również przyporządkowywali abstrakcyjnej sferze „pojęcia” („Begriff”) ${ }^{20}$, tyle że alegoria rezygnuje z wszelkich prób bezpośredniej (więc w zasadzie aporetycznej) reprezentacji kontaktu podmiotu $\mathrm{z}$ transcendencją. Nie może tu więc dojść do nieporozumień. Trzeba zresztą podkreślić, że relacja między transcendencją a immanencją (widzieliśmy, że można ją konstruować na różne sposoby) nie przekłada się samorzutnie na opozycję między sacrum a profanum. Są to różne płaszczyzny, zwłaszcza z punktu widzenia egzystencjalnego. Rzutuje to również na status symbolu (a także - pośrednio - alegorii). Kiedy sakralny absolut się „warunkuje”,

\footnotetext{
${ }^{18}$ Ibidem.

${ }^{19}$ Ibidem, 114.

${ }^{20}$ Ibidem, 336-337.
} 
dokonuje tego przez akty wcielenia. Ale relacja łącząca owe wcielenia z instancją wcielającą (można by określić ją jako część-całość) różni się istotnie, zarówno od wzoru Goetheańskiego („Urbild” wobec „odłamku”), jak i romantycznego (część jako „wszystkość” w continuum idei sztuki jako krytyki), choć na pierwszy rzut oka bliższy jej jest paradygmat romantyczny, tzn. aporetyczna koncepcja części-,„wszystkości”.

Właśnie w tym punkcie Benjamin spotyka się z Norwidem ${ }^{21}$. Łączy ich bowiem świadomość teologicznego ${ }^{22}$ zakorzenienia symbolu i przekonanie o przeinaczeniu tego rodowodu w romantycznych koncepcjach symbolu. Rozwijali tę świadomość jednak w innych, wręcz przeciwstawnych sobie kierunkach. Autorowi Vade-mecum udało się stworzyć poetykę, która poprzez rekontekstualizację tradycyjnych, tzn. „teologicznych” symboli chrześcijańskich przywróciła im ich pierwotną moc. Sfera sacrum wyłania się w twórczości Norwida spod warstwy konwencji „wieku przemysłowego i kupieckiego" 23 pozornie uniemożliwiającej wszelki kontakt z religijną istotą bycia. Odsłonięcie symboliczności takiej sytuacji równa się więc cudowi. Odczarowany świat nowoczesny zostaje znów zaczarowany. Benjamin uważał zaś, że aporetyczna istota symbolu teologicznego jest sprzeczna $z$ nowoczesnymi wyobrażeniami o ontologicznym statusie świata (właśnie dlatego zasięg oddziaływania symbolu został przez Schleglowski romantyzm ograniczony do sfery estetyki; albo odwrotnie: uprawnienia estetyki zostały rozszerzone poza jej własne granice).

Antynowoczesna istota symbolu skłoniła Benjamina do dowartościowania alegorii. Właśnie dzięki jej bardziej formalistycznemu charakterowi alegoria jest - zdaniem Benjamina - lepiej dostosowana do reprezentowania historycznej istoty nowoczesności. W odróżnieniu bowiem od pierwotnie aporetycznej, i właśnie dlatego ahistorycznej (skupiającej się z perspektywy 'historii świętej' na mistycznym 'teraz') istoty symbolu alegoria obrazuje dialektyczny ruch

${ }^{21}$ O Norwidzie i Benjaminie w kontekście tzw. Passagenwerk i Paryża Baudelaire’a napisał Krzysztof Trybuś, wspominając o znaczeniu alegorii dla obu poetów. Krzysztof Trybuś, Stary poeta. Studia o Norwidzie (Poznań: Wydawnictwo Naukowe UAM, 2000), 102, 119. Ten sam wątek wyeksponował trochę później Michał Kuziak w kontekście Norwidowskiego poematu Quidam: „Świat Quidama jest zbudowany z takich perspektyw, jednocześnie ich alegoryczność (w sensie Benjaminowskim), zrujnowanie, staje się wymiarem, w którym powstaje symbolizm, uobecnia się nadzieja, wizja możliwej całości - ponad fragmentami rzeczywistości i fragmentami tekstu”. Michał Kuziak, „Poetyka wielokulturowości w Quidamie”, in „Quidam”. Studia o poemacie, ed. Piotr Chlebowski (Lublin: Towarzystwo Naukowe KUL, 2011).

${ }^{22}$ Według Andreasa Pangritza trudno byłoby zrozumieć Benjamina bez „dokładnego zbadania wątków teologicznych w jego myśli”. Vide Andreas Pangritz, „Theologie”, in Benjamins Begriffe, ed. Michael Opitz, Erdmut Wizisla (Frankfurt a.M., 2000), vol. 2, 774. Wątki te pochodzą z mistyki żydowskiej, ale „często występują w historiozoficznym, estetycznym, a także politycznym przebraniu” (ibidem).

${ }^{23}$ Cf. Zofia Stefanowska, Strona romantyków. Studia o Norwidzie (Lublin: Towarzystwo Naukowe KUL, 1993) (zwłaszcza rozdział „Pisarz wieku kupieckiego i przemysłowego”). 
kształtujący nowoczesny świat, ruch, który zakłada znaturalizowaną, świecką (,restlose Säkularisierung des Historischen im Schöpfungsgegenstande”), w ostatecznym rachunku 'linearną koncepcję czasu, a właśnie w tym punkcie przeobraża się w stronę „rajskiego bezczasu” („Dem trostlosen Laufe der Weltchronik tritt nicht die Ewigkeit sondern die Restauration paradiesischer Zeitlosigkeit entgegen" ${ }^{24}$ ). Ów dialektyczny ruch nie traci znaczenia w świecie odartym z sacrum, zaś zadaniem literatury (szerzej: kultury) nowoczesnej jest artystyczne przedstawienie tej rzeczywistości. Ową światopoglądową podstawę opozycji między symbolem a alegorią Benjamin opisał jednak (to niewątpliwie paradoks!) na przykładzie przednowoczesnym, a mianowicie niemieckiego „dramatu żałobnego" baroku, która była głęboko zakorzeniona w sacrum; skupiał się przy tym na „alegorycznej kontemplacji”, uwydatniając „barokowe, świeckie przedstawienie historii jako dziejów cierpienia świata”.

Czy to właśnie ów barokowy kontekst rozważań Benjamina o alegorii tłumaczy obecność w nich wielu sformułowań, które przypominają Norwidowską koncepcję symbolu? Zwłaszcza napięcie między częścią a całością odgrywa tu istotną rolę. Wiąże się to $\mathrm{z}$ historycznym i kulturowym rozwarstwieniem, które stanowi czynnik konstytutywny przestrzeni Baroku, zarówno w literaturze, jak i w sztuce. Owo rozwarstwienie uwidacznia się również w barokowych dramatach. Forma „dramatu żałobnego” (Trauerspiel) składa się bowiem z fragmentów („Bruchstücke”) wywodzących się z (pogańskiej) starożytności (a także ze „Średniowiecznej” kultury chrześcijańskiej). Spiętrzając ułamki tradycji starożytnej - obrazy, aluzje mitologiczne, metafory, przysłowia etc. - barokowi poeci teatralni stwarzali - zdaniem Benjamina - dzieła-ruiny, których forma unaocznia przemijanie czasu jako objaw rozkładu i rozpadu. Chodzi tu więc o rodzaj czasowości w niczym nieprzypominającej mitycznego czasu przejawiającego się poprzez symbol, ale o aporetyczną strukturę temporalną. $\mathrm{Z}$ jednej strony przemijanie - z drugiej zaś bezczasowość jako restauracja stanu rajskiego. Owa równoczesność dwóch czasów ulega natychmiast uprzestrzennieniu („Die Geschichte wandert in den Schauplatz hinein" ${ }^{25}$ ). Pod tym względem barokowy dramat żałobny przeciwstawia się sztuce renesansowej, która wierzyła w możliwość odtwarzania wzorców antycznych jakby w próżni historycznej, w ich pierwotnej doskonałości, odizolowanej od teraźniejszości ${ }^{26}$. Jednakże owa ułamkowość zrujnowanej formy dramatu żałobnego nie stanowi negacji sfery teologicznej.

${ }^{24}$ Walter Benjamin, GS, vol. I.1, 270. „Naprzeciw ponurego biegu dziejów świata nie występuje wieczność, ale restauracja rajskiej bezczasowości”.

${ }^{25}$ Ibidem, 271.

${ }^{26}$ Cf. Walter Benjamin, Über den Begriff der Geschichte [O pojęciu historii]: „Die Geschichte ist Gegenstand einer Konstruktion, deren Ort nicht die homogene und leere Zeit, sondern die von Jetztzeit erfüllte bildet”. „Historia jest przedmiotem konstrukcji, której miejsca nie tworzy homogeniczny i pusty czas, ale którą wypełnia teraźniejszość”. 
Wręcz przeciwnie, perspektywa teologiczna zostaje tu jeszcze bardziej wywyższona. Celem spiętrzania fragmentów jest bowiem skonstruowanie punktu kulminacyjnego, czyli apoteozy, wskazującej na realność transcendencji, chociaż to, co boskie, nigdy nie przejawia się cieleśnie - nigdy bóstwo nie zstępuje do świata w postaci „plastycznego” (Goetheańskiego) symbolu „boskiego”.

Bardzo podobną strategię (choć - z drugiej strony - nie wolno zapominać o różnicach między chrześcijańską a żydowską tradycją teologiczną; u Benjamina nie ma mowy o typowym dla chrześcijańskiej historii świętej pojęciu „wcielenia”) w swoich tekstach stosuje Norwid, przedstawiając np. krajobraz ruin Rzymu, pogańskiej stolicy świata antycznego, na tle ,jasnego”, promiennego nieba, które poeta przyrównuje do twarzy Chrystusa:

- Cicho było - z daleka czerniał Ark Tytusa,

Koloseum, i Forum po przeciwnej stronie,

I oliw sad - - Firmament, jak lice Chrystusowe,

Wypogodzony bardzo, jasny od promieni,

$\mathrm{Z}$ historycznością onych na dole kamieni

Zgadzał się, jako gdy jest tło stosowne z twarzą,

Pejzaż z sceną dla której stanowić ma ramy ${ }^{27}$.

Okazuje się tu, że tło, czyli przypominający twarz Chrystusową firmament, przeobraża „pejzaż” w arenę (dla historii świętej), napełniając ją treścią symboliczną. W tym wierszu (trzeci z Pięciu zarysów pod znamiennym tytułem Ruiny) czasowość krajobrazu komplikuje się jeszcze bardziej: formy cywilizacji antycznej są bowiem wciąż obecne w nowoczesnej rzeczywistości, np. na cmentarzach, tyle że w tym nowym kontekście straciły swoje pierwotne znaczenie. Nie mogły zaś nabrać nowego, właśnie historycznego sensu, ponieważ, inaczej niż np. popękane szczątki Świątyni Pokoju, stały się formalnie doskonałymi, lecz ahistorycznymi ozdobami przeczącymi chrześcijańskiej wierze w zmartwychwstanie:

[...] Smętarze Chrześćjan z tej przyczyny

Gorszą mię; co dzień mówisz: „W ciała zmartwychwstanie

Wierzymy" - lecz smętarze tak są opuszczone,

Takie bezmyślne! - staro-greckie gadaniny,

Pojęte źle - jonickie, korynckie płakanie,

W herbach ze średnich wieków, z krzyżem jak orderem,

Przypiętym gwałtem - wszystko wyraźnie nieszczerem $[\ldots]^{28}$.

Właśnie pod tym względem różnią się te „starogreckie gadaniny” od autentycznych ruin, szczątków po epoce „pogańskiej”, które jako zdruzgotane relikty przeszłości (jako takie wchodzą do przedstawionej przez poetę chwili ukazującej

\footnotetext{
${ }^{27} \mathrm{PW}$, vol. 3, 488 .

${ }^{28}$ Ibidem, 489-490.
} 
swą własną przemijalność), uobecniają ruch czasu. Tylko taki moment może stawać się areną wcielenia Słowa (tzn. momentu wymykającego się normalnej czasowości i stanowiącego strukturalny odpowiednik Benjaminowskiego „bezczasu rajskiego"29; zaś jego przemijanie okazuje się więc zarówno u Norwida, jak i w analizowanym przez Benjamina niemieckim dramacie żałobnym warunkiem re-inscenizacji historii świętej (Benjamin analizuje tu sposób przejawienia się sacrum w poezji barokowej; jego własny mesjanizm miał być niesakralny). Łączy ich również to, że tematyzują swą własną perspektywę (trzeba przyznać, że w przypadku książki Benjamina, która miała być rozprawą habilitacyjną, nie było to takie proste ze względu na postulat „naukowej” bezstronności), przywołując „eklektyczny”, niespójny kontekst nowoczesności, która wyrzeka się sacrum w sensie wcielenia transcendencji, choć z drugiej strony nadal używa ona - ale jako rekwizytów, a nie symboli - motywów kiedyś służących jego uobecnianiu się). Różnica między nimi polega na tym, że Benjamin, opisując paradoksalną relację między historycznym w istocie czasem alegorii a „bezczasem rajskim”, nie utożsamia się z tą strukturą, lecz próbuje przede wszystkim udowodnić, że sformułowanie „granicznej” istoty barokowego dramatu żałobnego zakłada teologiczną perspektywę i użycie pojęć teologicznych ${ }^{30}$. Norwid zaś próbuje w kontekście historycznej rzeczywistości wieku Postępu znów odtworzyć tę aporię jako dowód żywotności chrześcijańskiej historii świętej.

3.

Ciekawy przy tym jest jeszcze inny fakt: zarówno Norwid, jak i Benjamin rozwinęli tę koncepcję na tle rozmyślań nad relacją między symbolem a alegorią, obecną w dziele Friedricha Creuzera (1771-1858). U Norwida wpływ tego romantycznego badacza mitów możemy jedynie pośrednio stwierdzićc ${ }^{31}$.

${ }^{29}$ GS, vol. I.1, 271. Różnica między zakorzenioną w żydowskiej tradycji historiozofią Benjamina a chrześcijańską koncepcją Norwida polega oczywiście na innej interpretacji obecności czynnika mesjańskiego. U Norwida wcielenie Chrystusa jest dokonanym faktem, chociaż trzeba je wciąż aktualizować i kontekstualizować. Dla Benjamina idea wcielenia jest niezrozumiała, ale za to (autor powołuje się tu na żydowski mesjanizm) przyszłość okazuje czasem naznaczonym piętna intensywnego oczekiwania: „Den Juden wurde die Zukunft aber darum noch nicht zur homogenen und leeren Zeit. Denn in ihr war jede Sekunde die kleine Pforte, durch die der Messias treten konnte" (GS, vol. I.2, 704). „Przyszłość dla Żydów dlatego właśnie nie staje się czasem pustym i jednorodnym. W niej każda sekunda może być niewielką bramą przez którą może nadejść Mesjasz".

${ }^{30} \mathrm{GS}$, vol. I.1, 390.

${ }^{31}$ Napisała o tym Grażyna Królikiewicz, „Symbol i mit w dziele Creuzera”, in Inspiracje Grecji antycznej $w$ dramacie doby romantyzmu. Rekonesans, ed. Maria Kalinowska (Toruń: Adam Marszałek, 2002), 34, 46. Vide Maciej Junkiert, Grecja i jej historia w twórczości Cypriana Norwida (Poznań: Wydawnictwo Naukowe UAM, 2012), 157-158, 322. Z punktu widzenia „historii świętej” zastanawiałem się nad różnicami między symbolem i alegorią u Norwida i Creuzera w tekście: A. van Nieukerken, „Cyprian Norwid, Friedrich Creuzer et les débuts du modernisme: symbole et allégorie”, in Norwid: notre contemporain, ed. Maria Delaperrière (Paris: Institut d'Etudes slaves, 2015), 97-113. 
Benjamin nawiązuje natomiast w Źródle dramatu żałobnego w Niemczech otwarcie do tego kontekstu. To właśnie Creuzerowi zawdzięcza on koncepcję reprezentacji [nie]obecności sacrum poprzez nagromadzenie fragmentów nabierających znaczeń symbolicznych lub alegorycznych. Niezwykle ważna, nie tylko dla Benjamina i Norwida, lecz dla całej literatury europejskiej, była zwłaszcza pierwsza księga pierwszego tomu słynnego dzieła tego autora o religiach starożytności pt. Symbolik und Mythologie der alten Völker ${ }^{32}$. W części poświęconej teorii symbolu niemiecki badacz, rozważając dwie podstawowe formy idei religijnych i filozoficznych u starożytnych (pierwsza z nich wywodzi się z symbolu, druga $\mathrm{z}$ mitu ${ }^{33}$ ), określa symbol jako naczynie dla boskiego promienia, uobecniające ogromny rozziew między sacrum a sposobem, w jaki ono zaistniało. Symbol ma więc - próbuję dookreślić myśl Creuzera - podwójną naturę, która jednak nie jest stale w nim obecna. Ujawnia się ona dopiero wtedy, kiedy byt, w którym rozbłyskuje światło bóstwa, traci swoją narzuconą przez konwencję jednoznaczność.

Und wie das Farbenspiel des Regenbogens durch das an der dunklen Wolke gebrochen Bild der Sonne entstehet, so wird das einfache Licht der Idee in einen farbigen Strahl von Bedeutsamkeit zerlegt. Denn bedeutsam und erwecklich wird das Symbol eben durch jene Incongruenz des Wesens mit der Form und durch die Überfülle des Inhalts im Vergleich mit seinem Ausdrucke. [...] Aus diesem Grunde haben es die Alten vorzüglich wirksam geachtet um den Menschen aus der Gewohnheit des täglichem Lebens zu einem höheren Bestreben zu erwecken ${ }^{34}$.

Symbol, albo raczej byt, który - w pewnych uprzywilejowanych chwilach - może się „usymbolić” (Norwidowski neologizm w postaci czasownika oddaje sens myśli Creuzera lepiej niż rzeczownik; symbol to nie tyle „rzecz”, ile „energia”), jest więc właśnie jako symbol bytem nietożsamym ze sobą. W szczytowych momentach realizuje wprawdzie swą istotę, tyle że nie o własnych siłach, lecz dzięki interwencji zstępującego na niego i podporządkowującego sobie jego przedmiotowość bóstwa. Chwile te, otwierające przed człowiekiem całość, której nie może on w pełni objąć - jest ona bowiem źródłową, nieskończoną

${ }^{32}$ Friedrich Creuzer, Symbolik und Mythologie der alten Völker, besonders der Griechen, erster Teil, zweite völlig umgearbeitete Ausgabe (Leipzig und Darmstadt, 1819). Poza niemieckim obszarem językowym dzieło to było na ogół czytane w opracowanej przez J.D. Guigniauta wersji francuskiej (właśnie w taki sposób zapoznał się z nim Norwid): Religions de l'Antiquité, considérées principalement dans leurs formes symboliques et mythologiques; ouvrage traduit de l'allemand du Dr Frédéric Creuzer, refondu en partie, complété et développé par J.D. Guigniaut, tome premier [...] (Paris [...] MDCCC XXV).

${ }^{33}$ Por. Friedrich Creuzer, op. cit., vol.1, 16.

${ }^{34}$ „Tak jak gra kolorów tęczy powstaje poprzez złamany obraz słońca na ciemnej chmurze, tak rozkłada się światło idei w barwnej wiązce sensowności. Symbol staje się bowiem ważny i budzący impulsy przez ową niezgodność istoty $\mathrm{z}$ formą i poprzez ogrom treści w porównaniu z jego wyrazem. [...] Z tej przyczyny starożytni nadzwyczaj cenili jego skuteczność, gdy chodziło o wybudzenie ludzi z przyzwyczajeń życia codziennego do dążenia ku wyższym celom”. 
całością ${ }^{35}$ - trwają jednak na ogół bardzo krótko. Życie codzienne odzyskuje prędko swoje prawa i przywraca światu jego bez- albo może raczej przedrefleksyjną, gładką i skończoną „całościowość”. Symbol otwiera więc szczelinę w masywnej obecności tego-samego, albo - żeby to jeszcze inaczej ująć - sam jest tą szczeliną, ukazując performatywnie, poprzez przeobrażenie swojej własnej natury, że tożsamość bytów zawiera się w ich podatności na nieskończony ciąg przeobrażeń. Różnicująca jakość energii symbolicznej, zdolną przeobrażać przedmioty, na które energia ta zstępuje, tak, że zaczynają świecić swoim światłem, Creuzer porównuje z błyskawicą:

Jenes Erweckliche und zuweilen Erschütternde hängt mit einer andern Eigenschaft zusammen, mit der Kürze. Es ist wie ein plötzlich erscheinender Geist, oder wie ein Blitzstrahl, der auf einmal die dunkle Nacht erleuchtet. Es ist ein Moment, der uns ganzes Wesen in Anspruch nimmt, ein Blick in eine schrankenlose Ferne, aus der unser Geist bereichert wiederkehrt ${ }^{36}$.

Jasność symbolu nie jest więc cechą przedmiotu, w którym rozbłyskuje przeobrażająca ów przedmiot energia symboliczna, lecz wyłania się z całokształtu („,das Totale”37) kontekstu w danej i niepowtarzalnej chwili (,das Momentane” ${ }^{38}$ ) zstąpienia bóstwa.

Creuzer odróżnia przy tym dwa rodzaje symboli. Pierwszy z nich - nazywa go symbolem „mistycznym” - odznacza się pragnieniem maksymalnego podobieństwa do Bożej nieskończoności. Chce ją objąć i wypowiedzieć w całości, i dlatego ulega - o ile jest formą - pęknięciu i rozproszeniu; staje się „chwiejący się”, „nieokreślony”, zagadkowy”:

Entweder folget das Symbol seinem natürlichen Hange, der auf das Unendliche gerichtet ist, und suchet, einzig bemühet, diesen zu befriedigen, vor allem nur recht bedeutsam zu seyn. In dieser Bestrebung genügt es ihn nicht, viel zu sagen; es will alles sagen. Es will das Unermeßliche ermessen, und das Göttliche in den engen Raum menschlicher Formen zwingen. Diese Ungenügsamkeit folget einzig dem dunklen Triebe des namenlosen Ahnens und Glaubens, und keiner Naturgesetze achtend, schweift sie über alle Gränzen aus, muß aber eben dadurch in schwebenden Unbestimmtheit räthselhaft werden. Hier waltet das Unaussprechliche vor, das, indem es Ausdruck suchet, zuletzt die irdische Form, als ein zu schwaches Gefäß, durch die unendliche Gewalt seines Wesens zersprengen wird. Hiermit ist aber sofort die Klarheit des Schauens selbst vernichtet, und es bleibt nur ein sprachloses Erstaunen übrig. Wir haben hiermit das Extrem bezeichnet, und nennen die Symbolik dieses Charakters die mystische, die jedoch,

${ }^{35}$ Por. Norwidowską definicję kontaktu między człowiekiem a Bogiem rozumianego jako akt poznawczy: „Boga? - że znikający nam przez doskonałość - / Nie widziałem, zaprawdę, jak widzi się całość [...]”. Cyprian Kamil Norwid, Do Walentego Pomiana Z., PW, vol. 2, 270.

${ }^{36}$ Friedrich Creuzer, op. cit., 59. „Owo pobudzające i niekiedy wstrząsające działanie wiąże się $\mathrm{z}$ inną jeszcze cechą, ze skrótowościa (natychmiastowością). Jest niczym nagle pojawiający się duch, albo jak błysk pioruna, który nagle rozjaśnia ciemną noc. Jest to chwila, która angażuje całą naszą istotę, spojrzenie w bezbrzeżną dal, skąd nasz duch powraca wzbogacony”.

${ }^{37}$ Ibidem, 64.

${ }^{38}$ Ibidem. 
wenn auch dieser Richtung hingegeben, solange sie noch Schranken anerkennt und nicht das Äußerste suchet, dem religiösen Glauben zum glücklichen, bedeutsamen Ausdrucke dienet ${ }^{39}$.

Okazuje się przy tym, że sukces symbolu „mistycznego” jako wyraz wiary wywodzi się - zdaniem Creuzera - z połowiczności jego realizacji, tzn. powinien on uznawać pewne granice, a nie dążyć do skrajności (wtedy „zamilknie”). Poza tym (jest to różnica zarówno z jenajskimi romantykami, jak i Goetheańskim klasycyzmem [Klassik]) względy „estetyczne” schodzą tu wyraźnie na plan dalszy, ponieważ owe granice decydujące o skuteczności symbolu mistycznego jako skończonego wyrazu nieskończoności są raczej przypadkowe, narzucone przez żywioł, w którym podmiot się zanurza. Nie ma tu mowy o samoograniczaniu się. Świadomość formy jako (estetycznego lub „krytycznego”) środka zapośredniczającego doświadczenia podmiotowe w przypadku symbolu mistycznego nie zostaje stematyzowana.

Drugi rodzaj symbolu, wobec faktu, że skończoność przez samą swoją naturę nie może zmieścić nieskończoności, narzuca sobie w tej mierze, w jakiej jest formą, pewne granice, dzięki czemu „udaje mu się, w jakiś sposób („gewissermaßen”) unaoczniać samo Bóstwo”. Strona idealna symbolu („das Wesen”) podporządkowuje się („füget sich”) formie, i właśnie dlatego „przenika ją i ożywia”. Dzięki temu świadomemu aktowi samoograniczenia - jedna strona symbolu składa się w ofierze drugiej - „sprzeczność między nieskończonością a skończonością zostaje rozwiązana”. Rzuca się tu w oczy, że Creuzer, formułując swoją tezę o naturze symbolu, personifikuje go:

Oder das Symbolische beschränkt sich selber und hält sich bescheiden auf der zarten Mittellinie zwischen Geist und Natur. In dieser Mäßigung gelingt ihm das Schwerste. Es vermag selbst das Göttliche gewissermaßen sichtbar zu machen. Also weit gefehlt, daß es nun der Bedeutsamkeit ermangele, wird es vielmehr höchst bedeutsam durch den großen Inhalt seines Wesens. Mit unwiderstehlicher Gewalt ziehet es den betrachtenden Menschen an sich, und nothwendig wie der Weltgeist selbst, greift es an unsere Seele. Es ist quellende Exuberanz lebendiger Ideen, die sich in ihm reget; und was die Vernunft, mit dem Verstande vereinigt, in successiver Schlußfolge erstrebet, das gewinnet sie hier, im Bunde mit dem Sinne, ganz und auf einmal.

${ }^{39}$ Ibidem, 62-63. „Symbol albo podąża za swoją naturalną skłonnością, a więc pragnieniem nieskończoności, i zabiega jedynie o to, by ją zaspokoić, a więc nade wszystko być prawdziwie znaczącym. W tym dążeniu nie wystarcza mu, że mówi dużo; on chce powiedzieć wszystko. Chce ocenić niezmierzone i wtłoczyć boskość w ciasną przestrzeń form ludzkich. Ta śmiałość/nieskromność kieruje się wyłącznie ciemnym popędem nienazwanego przeczuwania i wiary, i nie zważając na prawa natury przekracza wszelkie granice, ale właśnie dlatego będzie stanowiła zagadkę zawieszona w niedookreśloności. Panuje tutaj to, co jest niewypowiedziane, co w poszukiwaniu wyrazu niezmierzoną mocą swojej istoty w końcu roztrzaska ziemską formę, jako zbyt słabe naczynie. Tym samym jednak natychmiast zniszczona zostanie jasność patrzenia, i pozostanie tylko nieme zdziwienie. Opisaliśmy tym samym skrajność, symbolikę o mistycznym charakterze, która jednak, nawet jeśli oddana temu kierunkowi, dopóki uznaje granice i nie dąży do ostateczności, dopóty służy wierze religijnej jako szczęśliwy, ważny środek wyrazu”. 
Hier strebet das Wesen nicht zum Überschwenglichen hin, sondern, der Natur gehorchend, füget es sich in deren Form, durchdringet und belebet sie. Jener Widerstreit zwischen dem Unendlichen und dem Endlichen ist also aufgelöset, dadurch das jenes, sich selbst begränzend, ein Menschliches ward. Aus dieser Läuterung des Bildlichen einerseits, und aus der freiwilligen Verzichtleistung auf das Unermeßliche andrerseits, erblühet die schönste Frucht alles Symbolischen. Es ist das Göttersymbol, das die Schönheit der Form mit der höchsten Fülle des Lebens wunderbar vereinigt, und, weil es in der Griechischen Sculptur am vollendetsten ausgebildet ist, das plastische Symbol heißen kann ${ }^{40}$.

Trudno przeoczyć - choć sam Creuzer nie wyciąga tego wniosku - że sama definicja tego najdoskonalszego rodzaju symbolu w pewnym sensie powtarza dogmat wcielenia Chrystusa, tym bardziej gdy zastanawiamy się nad warunkami, w jakich symbol objawia swoją Boską naturę:

Jener Widerstreit zwischen dem Unendlichen und dem Endlichen ist also aufgelöset, dadurch das jenes, sich selbst begränzend, ein Menschliches ward. [...]

Diese höchsten Äußerungen des bildenden Vermögens nennen wir Symbole, und auf diesen engeren Kreis verkörperter Ideen sollte diese Benennung im wissenschaftlichen Gebrauche eingeschränkt bleiben. Sie sagt alles, was dieser Gattung eigenthümlich ist, und sie auf die höchste Stufe erhebt: das Momentane, das Totale, das Unergründliche ihres Ursprungs, das Nothwendige. Durch ein einziges Wort ist hier die Erscheinung des Göttlichen und die Verklärung des irdischen Bildes bezeichnet, und zwar, wie dargethan worden, ganz dem höheren Sprachgebrauche der Alten gemäß, die jedoch den Umfang dieses vielsagenden Worts auch auf geringere Begriffe ausdehnten ${ }^{41}$.

Trzeba jednak zaznaczyć, że owo rozwiązanie sprzeczności między nieskończonością a skończonością poprzez wcielenie tego pierwszego czynnika, „który,

${ }^{40}$ Ibidem, 63-64. „Albo też symboliczne ogranicza się samo i zatrzymuje się skromnie na subtelnej linii pomiędzy duchem a naturą. W tym umiarkowaniu udaje mu się rzecz najtrudniejsza. W pewnym sensie jest w stanie uczynić widzialnym nawet boskość. Byłoby więc dużym błędem sądzić, że brakuje mu znaczenia, treść jego istoty stanowi o jego ogromnym znaczeniu. Z nieodpartą mocą przyciąga do siebie przyglądającego się człowieka i niczym duch dziejów dotyka naszą duszę. Budzi się w nim tryskające bogactwo żywotnych idei; Rozsądek z rozwagą osiągają tutaj to, do czego sukcesywnie dążą, a dzieje się to w jedności ze zmysłami, całkowicie i momentalnie.

Tutaj istota nie dąży do egzaltacji, lecz słuchając natury, włącza się w jej formę, przenika i ożywia ją. Konflikt pomiędzy nieskończonym a skończonym rozwiązuje się, ponieważ owo, ograniczając samo siebie, staje się ludzkie. Oczyszczenie alegorycznego obrazu z jednej i dobrowolna rezygnacja z niezmierzonego z drugiej strony sprawiają, że rozkwita najpiękniejszy owoc wszystkiego co symboliczne. Jest to symbol bogów, który cudownie jednoczy piękno formy z najwyższym bogactwem życia i, ponieważ najdoskonalej ukształtował się w rzeźbie greckiej, może się nazywać symbolem plastycznym/twórczym".

${ }^{41}$ Ibidem, 64. „Konflikt pomiędzy nieskończonym a skończonym rozwiązuje się, ponieważ owo, ograniczając samo siebie, staje się ludzkie. [...]

Te najwspanialsze wyrazy twórczych możliwości nazywamy symbolami, i do tego wąskiego kręgu ucieleśnionych idei powinno ograniczać się to określenie w dziedzinie nauki. Wyraża ono wszystko, co jest właściwe temu gatunkowi i wynosi go na najwyższy poziom: momentalność, kompletność, tajemniczość jego pochodzenia, konieczność. Jedno jedyne słowo określa objawienie boskości i apoteozę ziemskiego obrazu, zgodnie z tym, jak je stosowali starożytni Grecy, którzy jednak poszerzali zakres tego wiele mówiącego słowa również na mniejsze pojęcia". 
samoograniczając się, stał się czymś ludzkim”, posiada w symbolu „plastycznym” przede wszystkim konotacje estetyczne (nieprzypadkowo kojarzy go Creuzer ze starogreckim rzeźbiarstwem). Wartości estetyczne wynikają zazwyczaj z kontemplacyjnej postawy podmiotu. Kontemplacja wydaje się jednak całkowicie sprzeczna $z$ wyodrębnionymi przez badacza warunkami koniecznymi dla objawienia się symboliczności jakiegoś przedmiotu lub sytuacji. Zakłada ona bowiem pewien „luz” czasowy (a nie „momentalność”), swobodę obcowania z symbolem (a nie „przymus”), wreszcie możliwość przechodzenia od całości do szczegółów, a następnie znów do zmodyfikowanej całości (nie zgadza się to z „totalnością" leżącą u podstaw doświadczenia symbolu). Symbol „boski” („Göttersymbol”) wydaje się więc contradictio in terminis.

Łatwo zrozumieć, że taki symbol nie mógł podobać się Benjaminowi. Brak w nim nie tylko reprezentacji nieskończoności (integralnym elementem takiej reprezentacji jest bowiem napięcie między „byciem” a nie-ujmującą go formą”, między „ideą” a jej - w zasadzie nieadekwatnym - wyrazem), nie może też być zgodny z nowoczesną koncepcją czasu linearnego (czasowość doświadczenia estetycznego ma raczej charakter cykliczny: od prowizorycznego wrażenia całości do szczegółów i znów z powrotem do zmodyfikowanej całości). A właśnie ta nowa, historyczna (nowożytna) czasowość uwidaczniała się - zdaniem Benjamina - już w tragedii barokowej, tyle że została tam jeszcze skojarzona z cudownością. W dramacie żałobnym to, co święte, nie utożsamia się samorzutnie z idealną, estetycznie „całą” - w sensie Creuzerowskiego symbolu boskiego - formą sztuki greckiej. Swoją formalną doskonałością sztuka ta zasłoniłaby bowiem pole dla wszelkich nowych, źródłowo transcendentnych objawień. Właśnie stąd bierze się w barokowym dramacie żałobnym tematyzacja ruchu ku sacrum poprzez popękaną formę.

Owa pozorna niedoskonałość jest więc warunkiem otwierania się przestrzeni dzieła na wymiar cudowności. Celem spiętrzenia fragmentów okazuje się skonstruowanie punktu kulminacyjnego, czyli „apoteozy”, wskazującej na realność transcendencji, chociaż to, co boskie nigdy nie przejawia się cieleśnie tu i teraz - nigdy bóstwo nie zstępuje w postaci "namacalnego" symbolu „boskiego" (tak było - według Creuzera - w greckiej sztuce starożytności), ani też w postaci popękanego symbolu mistycznego. To, co jest $\mathrm{w}$ istocie boskie, pozostaje poza naszym widnokręgiem. Forma (w szerokim sensie zwartości akcji, a także spójności motywacji, jakimi kierują się protagoniści) załamuje się nie tyle przez pragnienie objęcia tego, co nieskończone, w warunkach skończoności, ile z o wiele prostszej przyczyny. Nawet najmądrzejszy człowiek na tym padole „podksiężycowym" nie może do końca przewidywać następstw swoich czynów. Tragizm barokowego dramatu żałobnego zawiera się więc w koncepcji czasu jako stopniowego odsłaniania się konsekwencji niezharmonizowych z sobą, często sprzecznych aktów indywidualnej woli wielu osób. A właśnie tak można by zdefiniować otwarty czas 
nowoczesnej koncepcji historii. Jedynie moment zbawienia, wyzwolenia się spod jarzma czasowości historycznej, ma w tym świecie jeszcze charakter poza- albo bezczasowy, lecz to nie on decyduje o formie dramatu żałobnego.

Gdybyśmy więc wyeliminowali z rozważań Benjamina o niemieckim dramacie żałobnym transcendentny status sacrum, znaleźlibyśmy się twarzą w twarz z samym światem dziejów, składających się z luźno związanych fragmentów ludzkiej egzystencji, które są wyraźnie rozpoznawalne jako części opierające się wszelkim próbom integracji z perspektywy „metafizycznej” (opatrznościowej). A właśnie o reprezentację takiego świata Benjaminowi chodziło. W rozważaniach rozdziału o ,alegorii i dramacie żałobnym” dochodzi on do takiego punktu widzenia w paradoksalny sposób - poprzez postponowanie symbolu „boskiego" (umożliwiającego doskonałą immanentyzację sacrum) na rzecz symbolu „mistycznego”, który w konfrontacji z czasem historycznym ulega fragmentacji. Owa fragmentacja jest tu nie tyle - jak u Creuzera - logiczną konsekwencją nieprzystawalności nieskończoności do skończoności, ile raczej warunkiem wyeksponowania rozwarstwienia świata dziejów. Odcięcie symbolu mistycznego od jego transcendentnego rodowodu przeobraża go jednak w alegorię:

Aus dem mystischen 'Nu' wird das aktuelle 'Jetzt'; das Symbolische wird ins Allegorische verzerrt. Aus dem heilsgeschichtlichen Geschehen sondert man das Ewige ab und was bleibt, ist ein allen Korrekturen der Regie erreichbares lebendes Bild. Es entspricht das im Innersten der endlos vorbereitenden, umschweifigen, wollüstig zögernden Art der barocken Formgebung ${ }^{42}$.

Różnica między symbolem a (również omówioną przez Creuzera) alegorią polega na tym, że w obliczu obrazu alegorycznego podmiot zachowuje pewną swobodę interpretacyjną, podczas gdy symbol (,mistyczny”) poprzez swoją przymuszającą zdarzeniowość („das Nothwendige”43) włącza go nieodparcie w proces transformacji.

Podejście alegoryczne pozwala autorowi zachować dystans do procesu fragmentacji, której ulega symbol mistyczny. Nie jest bezwolnym uczestnikiem procesu symbolizowania się pewnego fragmentu bycia, ale staje się jego obserwatorem, ujmując sakralne objawienia na tle przemijającego czasu historycznego. $\mathrm{Na}$ chwilę czas się zatrzymuje (dzieje się tak przez podmiot i w nim), ale ów moment bezruchu (por. Creuzerowskie pojęcie „das Momentane”), w którym obserwator hic et nunc alegoryzuje ruiny przeszłości, nie jest sam w sobie spełnieniem czasów. Jest bowiem chwilą otwartą (otwierającą się) na wymykający się obserwatorowi czas „rajski”. Domaga się „dopełnienia”. Właśnie w tej jakości

${ }^{42}$ GS, vol. I.1, 358. „Mistyczne 'Nu' staje się aktualnym 'Teraz'; Symbol zniekształca się w alegorię. $\mathrm{Z}$ wydarzeń historycznych oddzielamy to co wieczne, a tym, co pozostaje, jest żywy obraz dostępny dla wszelkich korektur reżyserii. W swoim wnętrzu odpowiada on nieskończenie przygotowującej, peryfrazującej, rozkosznie ociągającej się sztuce form barokowych”.

${ }^{43}$ Friedrich Creuzer, op. cit., 64. 
czasu zawiera się mesjańska istota ludzkiej egzystencji. Obserwator obcuje wtedy $\mathrm{z}$,aniołem historii”, który odwrócił swoje oblicze w stronę tego, co minęło, lecz w tej samej chwili sam jest porwany przez „burzę wiejącą od raju” ${ }^{44}$, który pędzi go ku przyszłości, choć nadal pozostaje on twarzą w twarz z coraz bardziej, aż do nieba piętrzącymi się „odłamkami” przeszłości. Zdaniem Benjamina, autora wspomnianych już wyżej tez pt. Über den Begriff der Geschichte, właśnie ta porywająca wszystkich i wszystko burza jest „tym, co nazywamy przyszłością”, przy tym cała ta koncepcja (mimo że rzekomo odnosi się do Marksowskiego materializmu historycznego) jest raczej alegorią niż zwykłą „tezą” dyskursywną. Z Creuzerowską fenomenologią symbolu łączy ją jej „momentalność”, choć nie wydaje się ona wynikiem „przymusu”. Rewolucyjny woluntaryzm okazuje się tu niesprzeczny z zadaniem bycia obserwatorem treści dziejów. W rajską przyszłość owa burza porywa bowiem jednostkę konstruującą swoją egzystencję hic et nunc jako chwile jedyną w swoim rodzaju, choć zawierającą całą przeszłość. $\mathrm{O}$ ile u jenajskich romantyków takie chwile przekraczają siebie w stronę transcendencji dzięki temu, że są jaźniami, tzn. samozapośredniczającymi się zapośredniczeniami, o tyle u Benjamina cała przeszłość materializuje się w takiej indywidualnie przeżywanej chwili dzięki jej dynamicznej relacji z przyszłym rajem.

\section{ROMANTICISM OF JENA, CYPRIAN NORWID, WALTER BENJAMIN AND FRIEDRICH CREUZER: SYMBOL AND ALLEGORY}

\section{Su m m ary}

Comparative studies have established that Cyprian Norwid knew about Friedrich Creuzer's famous work on the symbol and mythology. He must at least have read its first volume, particularly the theoretical part (albeit in a French translation). Reading Creuzer aided him in reinterpreting his own concept of the symbol, presented in his early theoretical writings. His point of departure were Creuzer's remarks about "mystical" and "divine" symbols. Norwid's reinterpretation did not remain without consequences for his poetry. Recently several Norwid scholars have drawn attention to a fresh interpretative context: the concept of allegory elaborated by Walter Benjamin. They considered the context to be related to Benjamin's and Norwid's perception of the modern city (Paris from the "Passagenwerk") and also to the motive of ruins. Benjamin presented his concept of the allegory in his famous book Origin of German Tragic Drama. He developed it on the basis of the same considerations about the symbol (focusing in a "totalizing" and "necessary" way on the "mystical now") and allegory as Norwid once did. Here their paths converge. A precondition, however, for understanding Benjamin's remarks about the symbol is his $\mathrm{PhD}$ thesis The Concept of Art Criticism in German Romanticism that devotes much attention to reflexivity in the oeuvre of Novalis and Fr. Schlegel. This "Romanticism of Jena" and its philosophy of consciousness had also impact on Norwid (though mediated by Mickiewicz's "Parisian Lectures"). Comparing Norwid and Benjamin in these contexts contributes to defining their (differing) attitude towards the temporality of Being and the Holy.

${ }^{44}$ „Aber ein Sturm weht vom Paradiese her [...]”. GS, vol. I,2, 697-698. „Ale z raju nadciąga/ wieje burza". 